Article

\title{
How Does Tourist Experience Affect Environmentally Responsible Behavior?
}

\author{
Di Wu ${ }^{1}$, Kun Li ${ }^{1}$, Jia Ma ${ }^{1}$, Enxu Wang ${ }^{2, *}$ and Yang Zhu ${ }^{3}$ \\ 1 School of History, Culture and Tourism, Liaoning Normal University, Dalian 116081, China; \\ wudi0316@163.com (D.W.); lilikunvip@163.com (K.L.); majia1827@163.com (J.M.) \\ 2 Jangho Architecture College, Northeastern University, Shenyang 110169, China \\ 3 School of Business Administration, Dongbei University of Finance and Economics, Dalian 116025, China; \\ zhuyang20210101@163.com \\ * Correspondence: wangenxu@mail.neu.edu.cn
}

Citation: Wu, D.; Li, K.; Ma, J.; Wang, E.; Zhu, Y. How Does Tourist Experience Affect Environmentally Responsible Behavior? Sustainability 2022, 14, 924. https://doi.org/ $10.3390 /$ su14020924

Academic Editors: Elena

Carvajal-Trujillo and

David Castilla-Espino

Received: 22 November 2021

Accepted: 9 January 2022

Published: 14 January 2022

Publisher's Note: MDPI stays neutral with regard to jurisdictional claims in published maps and institutional affiliations.

Copyright: (C) 2022 by the authors. Licensee MDPI, Basel, Switzerland. This article is an open access article distributed under the terms and conditions of the Creative Commons Attribution (CC BY) license (https:// creativecommons.org/licenses/by/ $4.0 /)$.

\begin{abstract}
Mountain tourism is an important part of China's tourism market. Tourist behavior is essential to environmental protection and the sustainability of destinations. This paper takes environmentally responsible behavior (ERB) as an important tourist behavior. It breaks down the dimensions of the traditional tourism experience, such as hedonism, participation, novelty; or hedonism, involvement, novelty, local culture; and analyzes the influence of entertainment, education, aesthetics, and escape on place attachment from the nature of the tourism experience. It then incorporates nature bonding into the system of place attachment and analyzes the relationship with place attachment, tourist experiences, and ERBs in Qianshan Mountain, a 5A scenic spot in China. Partial least squares structural (PLS) equation modeling is used to analyze the data of 410 valid questionnaires. The results found that tourist experiences affect ERBs through place attachment. Nature bonding is the key factor of ERBs. The results are as follows: escape and aesthetics influence ERB through nature bonding; entertainment influences general ERB through place identity and nature bonding; education has a positive impact on general ERB through place identity and place dependence. Entertainment and education experiences partially affect place attachment. Place identity and nature bonding affect general ERB, but particular ERB is related only to nature bonding. The internal psychological mechanism of ERB is identified. In addition, mountain landscapes can be designed from the perspective of entertainment experiences, landscape aesthetic, leisure atmosphere and educational functions, so that tourists can spontaneously pay attention to environmental issues and engage in the practical activities of environmental protection.
\end{abstract}

Keywords: tourist experience; place attachment; environmentally responsible behavior; Qianshan Mountain

\section{Introduction}

Mountain tourism has been popular since the 19th century [1,2]. China is rich in mountain resources. Most of the world natural and cultural heritages are mountain tourism resources in China [3]. More than two billion people participate in mountain tourism in China every year, accounting for approximately 20 percent of the entire tourism market [4]. Therefore, mountain tourism occupies a central position in China's tourism market. However, most vulnerable mountain ecosystems are located in remote and poor areas with limited policy support and supervision capabilities [5]. In these areas, tourists' choosing, buying, consuming, and discarding tourism products and services cannot be regulated [6-8]; and local residents often pay more attention to economic benefits than to the protection of the mountain ecosystem, thus contributing to its degradation $[9,10]$.

To protect and conserve mountain tourism resources, environmentalist and tourism marketers try to improve tourists' ERB. ERB consists of behaviors that reflect the tourists' concern for the natural environment and for environmental problems [11-13]. It includes 
leaving local flora and fauna intact [14,15], conserving materials and energy [16], recycling [17], avoiding the discharge of pollutants [18,19], and traffic control $[20,21]$ in mountain ecosystems. Many scholars have explored these proactive factors in order to identify the mechanisms of ERB such as emotion [22,23], regulation [24,25], perceived value [26], and visitor participation and experience $[27,28]$. It was found that there were very few mandatory environmental regulations. In addition, tourists' internal psychological and emotional factors have an important impact on ERB [29-31]. Lee and Jan [32] considered that tourists' experience would be related to their ERBs; and built a model of recreation experience, environmental value, environmental attitude, and ERB. Cheng and $\mathrm{Wu}$ [33] constructed a framework of environmental knowledge, environmental sensitivity, place attachment, and ERB. They identified that the influence of place attachment is a mediating factor on ERB. Su et al. [25] constructed a model of eco-friendly reputation, emotional experience, and ERB, and identified that the eco-friendly reputation of a tourist destination and the emotional experience of tourists resulted in the formation of ERB. Zhou et al. [34] believed that the generation of ERB was a process of self-awareness. They found that tourist participation could directly generate ERB through the effect of relationship between the visitor and the destination quality. Confente and Scarpi [35] stated that the recognition of environmental consequences had an impact on ERB and verified that place attachment had an important moderating effect on ERB.

Previous studies have shown that ERB are affected by tourists' environmental attitudes. A pleasant trip often changes tourist behavior by associating positive ERB with the tourists' cognition and emotions. Therefore, enjoyable travel experiences will spontaneously generate ERBs. However, as a subjective psychological state, tourist experience is a multi-dimensional, comprehensive concept that consists of behavior, relationship, emotion, and cognition [36,37]. It leads to place attachment to the destination through behavior involvement [38-40]. If tourists experience place attachment to the destination, they focus on local environmental protection or environmental issues [23,41]. People who have place dependence and place identity support ERBs with action [42,43]. It is worth mentioning that nature bonding is an important concept relating to tourists' ERBs. This emotional connection between people and nature is an important part of place attachment in the sense of place $[44,45]$. Tourists come to understand and improve their understanding of the relationship between nature and people, which leads to ERBs [35,46]. However, previous studies have focused on the relationship between tourist experience or place attachment and ERB [43,47], and included little research about how tourist experience with place attachment affects ERB. Place attachment consists of two dimensions of place identity and place dependence $[48,49]$. This consideration of the emotional connection between people and nature, which is essential for tourists to demonstrate ERBs [50,51]. Therefore, this paper focuses on the fragile mountain ecosystem. It introduces the concept of place attachment and the ways in which tourists perform ERBs spontaneously in the psychological and emotional response to the human-land relationship, through the tourist experience. The tourism experience is divided into entertainment, education, aesthetics, and escape. To highlight the relationship between humans and nature, this paper breaks down the traditional two-dimensional place attachment framework, and factors nature bonding into the dimension of place attachment. It explains how different types of tourism experiences affect ERBs through place attachment, from the perspective of the emotional connection between humans and nature.

\section{Literature Review and Model Development \\ 2.1. Tourist Experience}

Tourism is a multidimensional interaction between humans and the environment [52]. Tourist activities such as visits, entertainment, learning, and enjoyment [53], are both physical and psychological experiences [54]. Tourists strengthen their relationship with a destination and generate positive emotions with, and attachment to, the destination through behavioral participation and interaction [55]. Tourist experiences generate pleasure 
states which form different dimensions [56]. Pine and Gilmore [38] and Oh et al. [53] divided the tourist experience into four dimensions of entertainment, education, aesthetics, and escape. Kim et al. [56] suggested that seven dimensions characterized a memorable tourism experience: hedonism, involvement, local culture, refreshment, meaningfulness, knowledge, and novelty. Tsai and Simon [57] categorized tourist experience in terms of hedonism, involvement, novelty, meaningfulness, refreshment, knowledge, and education. Gu et al. [58] identified seven dimensions: local culture, natural environments, natural landscapes, self-realization, social participation, consumption, relaxation, and recreation. This paper draws on the four dimensions of Pine and Gilmore [38] and Oh et al. [53]. These dimensions encompass the physical and mental components of tourist experiences, are consistent with mountain tourism [59], and are easy to evaluate in practice.

\subsection{Place Attachment}

Place attachment is part of environmental psychology and is defined as a positive emotional connection between a person and an environment. It also describes tourists ${ }^{\prime}$ feelings about a destination. Researchers have defined place attachment in terms of sense of place and community attachment. Williams and Vaske [48] measured people's feelings about a place in relation to place dependence and place identity. Raymond et al. [44] subdivided place attachment into place identity, place dependence, nature bonding, and social bonding. Kaltenborn and Bjørn [60] reported that place attachment consisted of natural and cultural attachment. Dutcher et al. [45] proposed two dimensions of community attachment: social and natural environment. This paper divides place attachment into place identity, nature bonding, and place dependence. This is because the traditional dimensions of place attachment that consist of place dependence and place identity tends to ignore the importance of the natural environment and interpersonal social bonding [44]. In the fourdimensional view of place attachment, social bonding is often used to describe the sense of belonging and emotional connection among groups in a community environment [61]. Nature bonding is a connection to the natural environment based on historical, emotional, or cognitive experiences [44]. The mountains have an excellent natural and ecological environment. As a dimension of place attachment, nature bonding is important to consider in relation to mountain tourism.

\subsection{Tourist Experience and Place Attachment}

The generation of place attachment depends on tourist participation and their understanding of the destination $[57,62,63]$. Interesting and impressive experiences can arouse place attachment $[52,64,65]$. The satisfaction of tourists with a variety of tourism experiences will deepen their emotional connection to the natural environment, and this connection will shape the place identity and nature bonding $[66,67]$. Unforgettable memories can also improve tourists' place identity or place dependence, confirming that "enjoying the natural environment" has a significant positive effect on place attachment [57,68-70]. Korpela et al. [71] also found that tourists liked to go to specific places for a pleasant experience. The aesthetic experience allows tourists to immerse themselves in nature at a destination [72]. Oh et al. [53] found that it was easy to generate tourist attachment to a destination in aesthetic experience. In rural tourism, a positive aesthetic experience strengthens place attachment for tourists [73]. Escape experience needs deeper immersion and more participation for tourists; however, they usually spend more time traveling to activities, so it is easier for them to establish place identity [74-76]. Tourists' emotional connection with a place is strengthened when they are in a place that is conducive to physical relaxation and spiritual recovery [77]. The knowledge of a destination's history, nature, and culture can promote place identity for tourists [77]. In addition, knowledge sharing behaviors of tourists can promote place attachment by increasing their participation at the destination [78]. Educating tourists on environmental protection can help them build an emotional and spiritual connection to the destination; and this connection is key to place attachment [79]. This leads to the following hypotheses: 
Hypothesis I. Tourist experience positively influences place attachment.

Hypothesis 1. Entertainment experience positively influences place attachment.

Hypothesis 1a. Entertainment experience positively influences place identity.

Hypothesis 1b. Entertainment experience positively influences nature bonding.

Hypothesis 1c. Entertainment experience positively influences place dependence.

Hypothesis 2. Aesthetic experience positively influences place attachment.

Hypothesis 2a. Aesthetic experience positively influences place identity.

Hypothesis 2b. Aesthetic experience positively influences nature bonding.

Hypothesis 2c. Aesthetic experience positively influences place dependence.

Hypothesis 3. Escapism experience positively influences place attachment.

Hypothesis 3a. Escapism experience positively influences place identity.

Hypothesis 3b. Escapism experience positively influences nature bonding.

Hypothesis 3c. Escapism experience positively influences place dependence.

Hypothesis 4. Education experience positively influences place attachment.

Hypothesis 4a. Education experience positively influences place identity.

Hypothesis 4 b. Education experience positively influences nature bonding.

Hypothesis 4c. Education experience positively influences place dependence.

\subsection{Environmentally Responsible Behavior}

ERB consists of energy conservation, waste avoidance, recycling, green mobility and transportation, green consumerism, and environmentally friendly social behaviors [17]. Smith-Sebasto and D'Costa [80] suggested dividing ERB into civic, educational, financial, legal, physical, and persuasion actions. Stern [81] proposed that ERB is classified into environmental activism, non-activist behaviors in the public sphere, private-sphere environmentalism, and other environmentally significant behaviors. Other researchers hold that ERB should be divided into general ERB and particular ERB [36,82]. General ERB includes everyday practices, such as disposing of garbage [83]. Particular ERB is specific to an environment, such as a tourism destination $[23,84]$. This two-dimensional view of ERB has been widely recognized $[85,86]$.

Baker and Crompton [59] have reported that if tourists are highly satisfied with their trip, they will be in a good psychological state that is conducive to positive tourism behaviors. Tourists will generate positive "human-to-land" emotions by interacting with the destinations and the natural environment. In the process, tourists emulate and learn environmental attitudes and behaviors [25]. In other words, tourists can experience place attachment through enhanced emotional connection and sense of belonging during their travel experiences. Tourists with deep place attachment will be more receptive to ERB and more protective of the environment [35]. Therefore, researchers believe that tourists are more likely to adopt pro-environment behaviors when they have a strong emotional connection to the destination $[87,88]$. 


\subsection{Place Attachment and ERB}

Previous studies have shown that place attachment affects ERB $[45,86]$. Cheng and $\mathrm{Wu}$ [33] found that individuals with a strong attachment to a place showed positive ERBs. Walker and Chapman [86] identified that tourists with place attachment would pick up other people's litter in a park. Ramkissoon et al. [83] and Tonge et al. [84] reported that interactive participation or emotional connection in a tourism experience had an impact on tourist ERB. Tourists with stronger place identity were more likely to be critical of behaviors that destroy the natural environment [89], a response that is related to their cognition and emotions. When tourists have special emotions about a destination, they tend to care about local environmental issues [90,91]. The positive memory formed in the tourism experience also affects place identity through cognition and emotion, leading to positive ERBs [87,88]. Stedman [92] found a significant positive correlation between place identity and willingness to take part in ERBs. Nature bonding gives tourists a sense of place attachment in a natural environment and promotes pro-environmental behaviors [28,90]. Place dependence influences tourists' ERBs by meeting tourists' functional needs in the destination and positive emotions are generated by the relationship [34]. Place attachment has direct and indirect effects on ERB [23,91]. This leads to the following hypotheses.

Hypothesis II. Place attachment positively influences ERB.

Hypothesis 5. Place identity positively influences ERB.

Hypothesis 5a. Place identity positively influences general ERB.

Hypothesis 5b. Place identity positively influences particular ERB.

Hypothesis 6. Nature bonding positively influences ERB.

Hypothesis 6a. Nature bonding positively influences general ERB.

Hypothesis 6b. Nature bonding positively influences particular ERB.

Hypothesis 7. Place dependence positively influences ERB.

Hypothesis 7a. Place dependence positively influences general ERB.

Hypothesis 7b. Place dependence positively influences particular ERB.

\section{Research Methods and Model Testing}

3.1. Questionnaire Design and Data Collection

\subsubsection{Questionnaire Design}

The data were collected with a questionnaire survey, and a structural equation model was used to test the hypotheses. To improve credibility and reliability, all variables were measured based on scales used in the literature; these were especially suitable for this study. For the Qianshan scenic spot, we consulted experts and staff to revise the questionnaire, and after the preliminary investigation and scale test, a formal scale was created. Oh et al.'s [53] four-part tourist experience model was adopted: entertainment, aesthetics, escape, and education. The items of place attachment were drawn from Raymond and Brown [44], and included four questions about place identity, four questions about nature bonding, and three questions about place dependence. The scale was based on findings regarding the measurement of general and particular ERB by Smith-Sebasto and D'Costa's [80] and Cheng et al. [86]. 
The subjects in this paper were Chinese tourists. To ensure the consistency of the content and expression in translation, we invited Chinese scholars and the managers of the scenic spot to review and revise the questionnaire, and native English speakers to review and correct the content. In addition, we conducted a reading test on the items with social personnel to ensure that there were no semantic errors or ambiguities in translation. We then composed the formal questionnaire.

The final questionnaire consisted of two parts. The first part measured tourist experience, place attachment and ERB ( $1=$ completely disagree, $7=$ completely agree $)$. The respondents were asked to express their degree of agreement with each measurement item on a 7-point Likert scale. The second part of the questionnaire collected the respondent's demographic information (gender, age, monthly income, education level, occupation) and the number of times they had been to Qianshan Mountain.

\subsubsection{Questionnaire Distribution and Data Collection}

Qianshan Mountain is located in the central part of Liaoning Province in northeast China $\left[123^{\circ} 4^{\prime} \mathrm{E}, 40^{\circ} \mathrm{N}\right]$. It is a national $5 \mathrm{~A}$ level scenic spot and a branch of the Changbai Mountains. Qianshan Mountain is at least 3.8 billion years old. This mountain resort with its temples and gardens is also famous for its stone pines, natural scenery, and historical sites. Qianshan Mountain's landforms and vegetation are valued for tourism and for scientific research.

To ensure that the respondents visited most of the scenic spots, the questionnaires were randomly distributed one-to-one at the exit of each of the scenic spots and the rest areas of Qianshan Mountain, 4-7 October 2019. The survey adhered to the principles of voluntary participation and anonymity for the protection of tourist privacy. A total of 540 questionnaires were distributed, and 525 copies were returned. Of these, 410 were valid, for an effective return rate of $75.9 \%$. Table 1 shows the demographic information of the 410 respondents. The result shows that women $(56.1 \%)$ outnumbered men $(43.9 \%)$, and $61.7 \%$ of tourists had attended university or earned a bachelor's degree. The sample accurately reflected the demographic characteristics of the tourists. The data from the 410 questionnaires was used for the structural equation analysis.

Table 1. Demographic Information of Participants $(n=410)$.

\begin{tabular}{|c|c|c|c|}
\hline Variable & Category & Frequency & Percentage (\%) \\
\hline \multirow{3}{*}{ Gender } & Male & 180 & 43.9 \\
\hline & Female & 230 & 56.1 \\
\hline & 18 and under & 40 & 9.8 \\
\hline \multirow{5}{*}{ Age } & 19-25 & 72 & 17.6 \\
\hline & $26-30$ & 88 & 21.5 \\
\hline & $31-40$ & 86 & 21.0 \\
\hline & $41-50$ & 54 & 13.2 \\
\hline & $51-60$ & 38 & 9.3 \\
\hline \multirow{6}{*}{$\begin{array}{l}\text { Monthly income } \\
\text { (RMB) }\end{array}$} & Over 60 & 32 & 7.8 \\
\hline & Under 3000 & 102 & 24.9 \\
\hline & $3001-5000$ & 188 & 45.9 \\
\hline & $5001-7000$ & 92 & 22.4 \\
\hline & $7001-10,000$ & 13 & 3.2 \\
\hline & Above 10,000 & 15 & 3.7 \\
\hline \multirow{5}{*}{ Education Level } & Junior middle school and below & 58 & 14.1 \\
\hline & $\begin{array}{l}\text { Senior high school and } \\
\text { vocational high school }\end{array}$ & 71 & 17.3 \\
\hline & Junior college & 99 & 24.1 \\
\hline & Undergraduate & 154 & 37.6 \\
\hline & Master's degree or above & 28 & 6.8 \\
\hline Occupation & Students & 75 & 18.3 \\
\hline
\end{tabular}


Table 1. Cont.

\begin{tabular}{cccc}
\hline Variable & Category & Frequency & Percentage (\%) \\
\hline & Civil servant & 48 & 11.7 \\
& Personnel of enterprises and & 99 & 24.1 \\
& institutions & 55 & 13.4 \\
& Individual business operators & 45 & 11.0 \\
& Freelance & 46 & 11.2 \\
& Retiree & 42 & 10.2 \\
Travel frequency & Others & 63 & 64.4 \\
& Once a year & 265 & 17.1 \\
& $2-3$ times each year & 70 & 2.9 \\
4-5 times each year & 12 & 66.3 \\
Times of visit & More than 5 times a year & 272 & 21.7 \\
Qianshan Mountain & First time & 89 & 3.9 \\
& Second time & 16 & 8.0 \\
Number of days in & Third time & 33 & 81.0 \\
\hline
\end{tabular}

\subsection{Results}

\subsubsection{Measurement Model}

The Partial Least Square (PLS) method was used to analyze the relationship among latent variables. The main reason was that PLS-SEM is suitable for predictive research [93] and can test the robustness of a model [94]. PLS-SEM does not require the measured variable data to comply with the normal distribution and thus does not overemphasize the nonlinear effect [95]. It was therefore suitable for this study.

The evaluation indexes for the measurement model were reliability, convergent validity, and discriminant validity. The results of the measurement model, in Table 2 , show that the composite reliability (CR) and Cronbach's alpha of each variable were greater than 0.7 , showing good stability. Construction validity includes convergent validity and discriminant validity. The minimum factor loading of the questions was 0.731 , which was higher than the critical value of 0.7 . The average variance extracted (AVE) was between 0.676 and 0.776 , also above the critical value of 0.5 . This means that there was good convergent validity between the questions measuring the same variable. This paper used the Fornell-Larcker criterion to evaluate the discriminant validity. This approach holds that the square root of AVE for each variable needs to be greater than the highest correlation of any other structure. Table 2 shows that every variable used in the model met this requirement.

The analysis showed that the reliability and validity of each latent variable in the model met the corresponding standards. The measurement model therefore had good reliability and validity.

Table 2. Measurement Model Results.

\begin{tabular}{|c|c|c|c|c|c|c|c|}
\hline Construct and Indicators & Mean & SD & Loadings & AVE & CR & $\begin{array}{l}\text { Cronbach's } \\
\text { Alpha }\end{array}$ & $\begin{array}{l}\text { Discriminant } \\
\text { Validity }\end{array}$ \\
\hline Entertainment & & & & 0.708 & 0.906 & 0.862 & 0.841 \\
\hline $\begin{array}{l}\text { Being in Qianshan Mountain made } \\
\text { me pleasant and relaxed }\end{array}$ & 5.473 & 1.462 & 0.896 & & & & \\
\hline $\begin{array}{l}\text { Traveling in Qianshan Mountain was } \\
\text { amusing }\end{array}$ & 5.407 & 1.219 & 0.877 & & & & \\
\hline $\begin{array}{c}\text { Traveling in Qianshan Mountain } \\
\text { made me surprised }\end{array}$ & 5.254 & 1.282 & 0.769 & & & & \\
\hline $\begin{array}{c}\text { I really enjoyed visiting Qianshan } \\
\text { Mountain }\end{array}$ & 5.334 & 1.304 & 0.818 & & & & \\
\hline
\end{tabular}


Table 2. Cont.

\begin{tabular}{|c|c|c|c|c|c|c|c|}
\hline Construct and Indicators & Mean & SD & Loadings & AVE & CR & $\begin{array}{l}\text { Cronbach's } \\
\text { Alpha }\end{array}$ & $\begin{array}{l}\text { Discriminant } \\
\text { Validity }\end{array}$ \\
\hline Aesthetics & & & & 0.684 & 0.894 & 0.846 & 0.827 \\
\hline $\begin{array}{c}\text { The scenery in Qianshan Mountain } \\
\text { was very attractive }\end{array}$ & 5.527 & 1.202 & 0.893 & & & & \\
\hline $\begin{array}{l}\text { The environment in Qianshan } \\
\text { Mountain was exciting }\end{array}$ & 5.120 & 1.291 & 0.731 & & & & \\
\hline $\begin{array}{l}\text { The setting of Qianshan Mountain } \\
\text { was unique }\end{array}$ & 5.178 & 1.175 & 0.854 & & & & \\
\hline $\begin{array}{c}\text { Qianshan Mountain gave me a sense } \\
\text { of harmony }\end{array}$ & 5.268 & 1.303 & 0.823 & & & & \\
\hline Escapism & & & & 0.706 & 0.906 & 0.861 & 0.840 \\
\hline $\begin{array}{l}\text { Being in Qianshan Mountain made } \\
\text { me feel like I had escaped from reality } \\
\text { I felt that the environment of }\end{array}$ & 5.288 & 1.198 & 0.850 & & & & \\
\hline $\begin{array}{l}\text { Qianshan Mountain was different } \\
\text { from that of my daily life }\end{array}$ & 5.432 & 1.267 & 0.789 & & & & \\
\hline $\begin{array}{l}\text { I felt like part of Qianshan } \\
\text { Mountain's environment }\end{array}$ & 5.180 & 1.192 & 0.888 & & & & \\
\hline $\begin{array}{l}\text { On this trip, I was so absorbed that I } \\
\text { forgot everything else }\end{array}$ & 5.173 & 1.362 & 0.832 & & & & \\
\hline Education & & & & 0.676 & 0.893 & 0.840 & 0.822 \\
\hline $\begin{array}{l}\text { The trip to Qianshan Mountain } \\
\text { taught me a lot about the mountain }\end{array}$ & 4.734 & 1.338 & 0.758 & & & & \\
\hline $\begin{array}{l}\text { The trip to Qianshan Mountain has } \\
\text { made me more knowledgeable }\end{array}$ & 4.661 & 1.295 & 0.825 & & & & \\
\hline $\begin{array}{l}\text { The trip to Qianshan Mountain has } \\
\text { helped and inspired me in my work } \\
\text { and life }\end{array}$ & 4.695 & 1.333 & 0.865 & & & & \\
\hline $\begin{array}{l}\text { This trip stimulated my curiosity to } \\
\text { learn more about Qianshan Mountain }\end{array}$ & 4.675 & 1.488 & 0.837 & & & & \\
\hline Place Identity & & & & 0.689 & 0.898 & 0.850 & 0.830 \\
\hline $\begin{array}{l}\text { I liked Qianshan Mountain very } \\
\text { much }\end{array}$ & 5.529 & 1.208 & 0.831 & & & & \\
\hline $\begin{array}{c}\text { It was important for me to visit } \\
\text { Qianshan Mountain }\end{array}$ & 5.307 & 1.270 & 0.865 & & & & \\
\hline $\begin{array}{l}\text { The tourist experience in Qianshan } \\
\text { Mountain was very special to me }\end{array}$ & 5.078 & 1.151 & 0.831 & & & & \\
\hline $\begin{array}{l}\text { The tourist experience in Qianshan } \\
\text { Mountain was a part of me }\end{array}$ & 4.893 & 1.237 & 0.791 & & & & \\
\hline Nature Bonding & & & & 0.720 & 0.912 & 0.871 & 0.849 \\
\hline $\begin{array}{l}\text { I was very satisfied with the natural } \\
\text { environment of Qianshan Mountain }\end{array}$ & 5.290 & 1.180 & 0.834 & & & & \\
\hline $\begin{array}{c}\text { I felt calm when I spent time in the } \\
\text { natural environment of Qianshan } \\
\text { Mountain }\end{array}$ & 5.095 & 1.233 & 0.876 & & & & \\
\hline $\begin{array}{l}\text { Being in the natural environment of } \\
\text { Qianshan Mountain increased my } \\
\text { understanding of myself }\end{array}$ & 4.841 & 1.234 & 0.841 & & & & \\
\hline $\begin{array}{l}\text { When I was in the natural } \\
\text { environment of Qianshan Mountain, } \\
\text { I felt at one with the environment }\end{array}$ & 4.912 & 1.275 & 0.843 & & & & \\
\hline Place Dependence & & & & 0.776 & 0.912 & 0.856 & 0.881 \\
\hline $\begin{array}{l}\text { No place can meet my needs better } \\
\text { than Qianshan Mountain }\end{array}$ & 4.861 & 1.209 & 0.859 & & & & \\
\hline $\begin{array}{c}\text { No other place can compare with } \\
\text { Qianshan Mountain }\end{array}$ & 4.571 & 1.281 & 0.905 & & & & \\
\hline $\begin{array}{l}\text { No other place can replace my } \\
\text { experience in Qianshan Mountain }\end{array}$ & 4.534 & 1.360 & 0.878 & & & & \\
\hline
\end{tabular}


Table 2. Cont.

\begin{tabular}{|c|c|c|c|c|c|c|c|}
\hline Construct and Indicators & Mean & SD & Loadings & AVE & CR & $\begin{array}{c}\text { Cronbach's } \\
\text { Alpha }\end{array}$ & $\begin{array}{c}\text { Discriminant } \\
\text { Validity }\end{array}$ \\
\hline General behavior & & & & 0.769 & 0.930 & 0.900 & 0.877 \\
\hline $\begin{array}{l}\text { I will read some reports or books } \\
\text { about the environment in Qianshan } \\
\text { Mountain }\end{array}$ & 4.500 & 1.252 & 0.867 & & & & \\
\hline $\begin{array}{c}\text { I will work hard to learn how to solve } \\
\text { the environmental problems in } \\
\text { Qianshan Mountain }\end{array}$ & 4.283 & 1.313 & 0.900 & & & & \\
\hline $\begin{array}{l}\text { I will discuss the environmental } \\
\text { protection of Qianshan Mountain } \\
\text { with people }\end{array}$ & 4.363 & 1.399 & 0.905 & & & & \\
\hline $\begin{array}{l}\text { I will try my best to persuade my } \\
\text { friends to protect the natural } \\
\text { environment of Qianshan Mountain }\end{array}$ & 4.612 & 1.563 & 0.833 & & & & \\
\hline Particular behavior & & & & 0.773 & 0.932 & 0.903 & 0.879 \\
\hline $\begin{array}{l}\text { If there is rubbish on the road, I will } \\
\text { pick it up }\end{array}$ & 4.754 & 1.537 & 0.880 & & & & \\
\hline $\begin{array}{l}\text { I would like to take part in cleaning } \\
\text { up the mountain }\end{array}$ & 4.446 & 1.654 & 0.842 & & & & \\
\hline If there is any damage to Qianshan & & & & & & & \\
\hline $\begin{array}{c}\text { Mountain, I will stop it by legal } \\
\text { means }\end{array}$ & 4.405 & 1.640 & 0.907 & & & & \\
\hline $\begin{array}{l}\text { If someone damages the environment } \\
\text { in Qianshan Mountain, I will inform } \\
\text { the relevant authorities }\end{array}$ & 4.471 & 1.741 & 0.888 & & & & \\
\hline
\end{tabular}

\subsubsection{Structural Model}

The significance of path coefficients underwent bootstrap testing in PLS. The results are shown in Table 3 and Figure 1.

Hypotheses $\mathrm{H} 1, \mathrm{H} 2, \mathrm{H} 3$, and $\mathrm{H} 4$ were proven, showing that the tourism experience had positive effects on place attachment.

$\mathrm{H} 1$ (H1a, H1b, H1c) partially verified the positive influence of entertainment experience on place attachment of the mountain tourists. It was found that entertainment experience positively affected place identity $(\beta=0.277, p<0.001)$ and nature bonding ( $\beta=0.151, p<0.025)$. The hypothesis that entertainment experience positively affects place dependence $(\beta=0.083, p=0.229>0.05)$ did not pass the significance test of the path coefficient. Therefore, $\mathrm{H} 1$ was only partially supported.

$\mathrm{H} 2(\mathrm{H} 2 \mathrm{a}, \mathrm{H} 2 \mathrm{~b}, \mathrm{H} 2 \mathrm{c})$ posited that aesthetic experience positively affects place attachment. The path coefficient and the test result showed that for the mountain tourists', the aesthetic experience positively affected place identity $(\beta=0.258, p<0.001)$, nature bonding ( $\beta=0.305, p<0.001)$, and place dependence $(\beta=0.332, p<0.001)$. All the sub-hypotheses were proven valid. Thus, the hypothesis that the mountain tourists' aesthetic experience positively affects their place attachment was supported.

$\mathrm{H} 3(\mathrm{H} 3 \mathrm{a}, \mathrm{H} 3 \mathrm{~b}, \mathrm{H} 3 \mathrm{c})$ proposed that escape experience has a positive effect on place attachment. It was shown that the mountain tourists' escape experience had significant positive effects on place identity $(\beta=0.275, p<0.001)$, nature bonding $(\beta=0.374, p<0.001)$, and place dependence $(\beta=0.196, p<0.05)$. H3 was therefore supported.

$\mathrm{H} 4$ (H4a, H4b, H4c) held that educational experience positively affects place attachment. The mountain tourists' education experience had a significant impact on place identity $(\beta=0.196, p<0.05)$, and place dependence $(\beta=0.150, p<0.001)$. However, education experience directly influenced nature bonding $(\beta=0.080, p=0.070>0.05)$. Therefore, H4 was partially proved.

In addition, this paper hypothesized that the mountain tourists' place attachment positively affects ERB. It was proven by $\mathrm{H} 5, \mathrm{H} 6$ and $\mathrm{H} 7$. 
$\mathrm{H} 5$ (H5a and $\mathrm{H} 5 \mathrm{~b})$ posited that the mountain tourists' place identity positively affects their ERB. The results show that place identity positively influenced general ERB $(\beta=0.164$, $p<0.05)$ and had no direct impact on particular $\operatorname{ERB}(\beta=0.094, p=0.240>0.05)$. H5 was therefore partially supported.

Table 3. The Results of Hypotheses.

\begin{tabular}{cccc}
\hline Hypotheses & Coefficient & t-Values & Result \\
\hline H1a: Entertainment $\rightarrow$ Place identity & $0.277^{* * *}$ & 4.010 & Supported \\
H1b: Entertainment $\rightarrow$ Nature bonding & $0.151^{*}$ & 2.244 & Supported \\
H1c: Entertainment $\rightarrow$ Place dependence & 0.083 & 1.202 & Not supported \\
H2a: Aesthetics $\rightarrow$ Place identity & $0.258^{* * *}$ & 3.591 & Supported \\
H2b: Aesthetics $\rightarrow$ Nature bonding & $0.305^{* * *}$ & 4.382 & Supported \\
H2c: Aesthetics $\rightarrow$ Place dependence & $0.332^{* * *}$ & 4.815 & Supported \\
H3a: Escapism $\rightarrow$ Place identity & $0.275^{* * *}$ & 3.883 & Supported \\
H3b: Escapism $\rightarrow$ Nature bonding & $0.374^{* * *}$ & 5.518 & Supported \\
H3c: Escapism $\rightarrow$ Place dependence & $0.196^{* *}$ & 2.893 & Supported \\
H4a: Education $\rightarrow$ Place identity & $0.126^{* *}$ & 2.867 & Supported \\
H4b: Education $\rightarrow$ Nature bonding & 0.080 & 1.810 & Not supported \\
H4c: Education $\rightarrow$ Place dependence & $0.150^{* * *}$ & 3.222 & Supported \\
H5a: Place identity $\rightarrow$ General behavior & $0.164^{*}$ & 2.279 & Supported \\
H5b: Place identity $\rightarrow$ Particular behavior & 0.094 & 1.176 & Not supported \\
H6a: Nature bonding $\rightarrow$ General behavior & $0.374^{* * *}$ & 4.537 & Supported \\
H6b: Nature bonding $\rightarrow$ Particular behavior & $0.352^{* * *}$ & 4.239 & Supported \\
H7a: Place dependence $\rightarrow$ General behavior & 0.026 & 0.397 & Not supported \\
H7b: Place dependence $\rightarrow$ Particular behavior & 0.061 & 1.043 & Not supported \\
\hline Note: ${ }^{* * *} p<0.001, * * p<0.01, * p<0.05$. & & &
\end{tabular}

\section{Tourist experience}

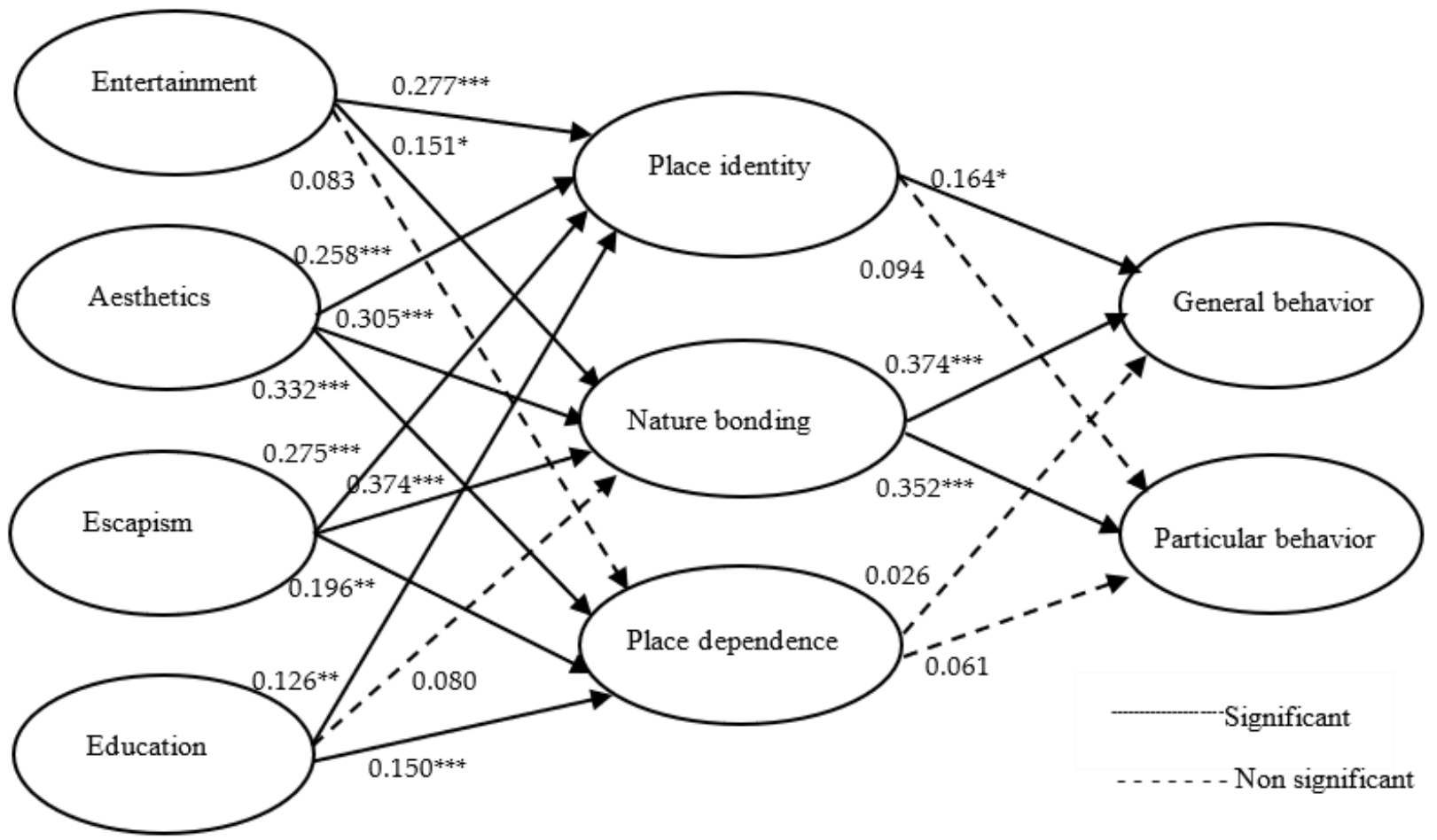

Figure 1. Structural model results (Note: ${ }^{* *} p<0.001,{ }^{* *} p<0.01,{ }^{*} p<0.05$ ). 
H6 (H6a and H6b) posited that the mountain tourists' nature bonding positively affects their ERB. Table 3 shows that nature bonding had a positive effect on general ERB $(\beta=0.374, p<0.001)$ and particular $\operatorname{ERB}(\beta=0.352, p<0.001)$, which fully supported the hypothesis that nature bonding has a significant effect on ERB.

$\mathrm{H7}(\mathrm{H7a}$ and $\mathrm{H7b}$ ) posited that the mountain tourists' place dependence positively affects their ERB. The results showed that place dependence did not influence general ERB $(\beta=0.026, p=0.692>0.05)$ or particular $\operatorname{ERB}(\beta=0.061, p=0.297>0.05)$. It completely refuted the hypothesis that place dependence positively affects ERB. H7 was not proved.

PLS-SEM was used to predict the SEM in this paper. The explanatory abilities of this model for place identity, nature bonding, and place dependence were $68.5 \%, 67.1 \%$, and $44.4 \%$, respectively. The explanatory power of general and particular ERB were $28.5 \%$ and $22.7 \%$, respectively. These values of explanatory power are much higher than the standard proposed by Hair et al. [96]. This means that $\mathrm{R}^{2}$ is greater than or equal to $20 \%$ in consumer behavior research; which is considered to have high explanatory power. Overall goodness of fit index of PLS-SEM was obtained by calculating the square root of product of AVE and average of $\mathrm{R}^{2}$. The goodness-of-fit index of the model was higher than the critical value of 0.36-0.578, meaning that the model was a good fit.

Furthermore, the statistics showed that the percentage of women respondents (56.1\%) was higher than the percentage of men (43.9\%). Of the respondents, $61.7 \%$ had a bachelor's degree, roughly consistent with the demographic and educational statistics provided by the Chinese government. At the same time, this paper used SPSS to conduct an independent sample T-test to explore whether there were significant gender differences in the tourist experience, place attachment or ERB. The results showed that the significant values of tourist experience, place attachment and ERB in the mean T-test are greater than 0.05, which means that there was no difference. The results are shown in Table 4. 
Table 4. Independent Sample T-test Results of Gender on Tourist Experience, Place Attachment and Environmentally Responsible Behavior.

\begin{tabular}{|c|c|c|c|c|c|c|c|c|c|c|c|}
\hline & & & \multicolumn{5}{|c|}{ Levene Test of Variance Equation } & \multicolumn{4}{|c|}{ T-Test of Mean Value Equation } \\
\hline & & & $\mathbf{F}$ & Sig. & $\mathbf{T}$ & df & $\begin{array}{c}\text { Sig. } \\
\text { (Bilateral) }\end{array}$ & $\begin{array}{c}\text { Mean } \\
\text { Difference }\end{array}$ & $\begin{array}{l}\text { Standard Error } \\
\text { Value }\end{array}$ & $\begin{array}{l}95 \% \text { Confidence } \\
\text { Lower Limit }\end{array}$ & $\begin{array}{l}\text { al of Difference } \\
\text { Upper Limit }\end{array}$ \\
\hline \multirow{7}{*}{$\begin{array}{l}\text { Tourist } \\
\text { Experience }\end{array}$} & \multirow[b]{2}{*}{ Entertainment } & Equal variances assumed & 4.574 & 0.033 & 0.397 & 408 & 0.692 & 0.17536 & 0.44217 & -0.69386 & 1.04459 \\
\hline & & Equal variances not assumed & & & 0.401 & 398.258 & 0.689 & 0.17536 & 0.43736 & -0.68445 & 1.03518 \\
\hline & \multirow{2}{*}{ Aesthetic } & Equal variances assumed & 0.870 & 0.357 & -0.379 & 408 & 0.705 & -0.15531 & 0.40943 & -0.96016 & 0.64954 \\
\hline & & Equal variances not assumed & & & -0.381 & 388.929 & 0.704 & -0.15531 & 0.40818 & -0.95782 & 0.64719 \\
\hline & \multirow{2}{*}{ Escapism } & Equal variances assumed & 3.326 & 0.069 & -0.995 & 408 & 0.320 & -0.41763 & 0.41956 & -1.24241 & 0.40714 \\
\hline & & Equal variances not assumed & & & -1.003 & 394.332 & 0.317 & -0.41763 & 0.41649 & -1.23644 & 0.40118 \\
\hline & Education & Equal variances assumed & 0.201 & 0.654 & -1.140 & 408 & 0.255 & -0.50918 & 0.44679 & -1.38747 & 0.36911 \\
\hline \multirow{6}{*}{$\begin{array}{c}\text { Place } \\
\text { attachment }\end{array}$} & \multirow{2}{*}{$\begin{array}{c}\text { Place } \\
\text { identity }\end{array}$} & Equal variances assumed & 0.000 & 0.992 & -0.098 & 408 & 0.922 & -0.03961 & 0.40302 & -0.83186 & 0.75263 \\
\hline & & Equal variances not assumed & & & -0.098 & 381.159 & 0.922 & -0.03961 & 0.40396 & -0.83389 & 0.75466 \\
\hline & \multirow{2}{*}{ Nature bonding } & Equal variances assumed & 1.236 & 0.267 & 0.142 & 408 & 0.887 & 0.05918 & 0.41691 & -0.76038 & 0.87873 \\
\hline & & Equal variances not assumed & & & 0.143 & 394.710 & 0.886 & 0.05918 & 0.41372 & -0.75419 & 0.87254 \\
\hline & \multirow{2}{*}{ Place dependence } & Equal variances assumed & 0.688 & 0.407 & -0.025 & 408 & 0.980 & -0.00845 & 0.33882 & -0.67451 & 0.65760 \\
\hline & & Equal variances not assumed & & & -0.025 & 374.123 & 0.980 & -0.00845 & 0.34112 & -0.67921 & 0.66230 \\
\hline \multirow{4}{*}{ ERB } & \multirow{2}{*}{ General behavior } & Equal variances assumed & 0.117 & 0.732 & -1.037 & 408 & 0.300 & -0.50048 & 0.48262 & -1.44921 & 0.44824 \\
\hline & & Equal variances not assumed & & & -1.037 & 385.141 & 0.300 & -0.50048 & 0.48245 & -1.44906 & 0.44809 \\
\hline & \multirow{2}{*}{ Particular behavior } & Equal variances assumed & 0.003 & 0.958 & -1.317 & 408 & 0.188 & -0.75870 & 0.57592 & -1.89083 & 0.37344 \\
\hline & & Equal variances not assumed & & & -1.314 & 380.257 & 0.190 & -0.75870 & 0.57761 & -1.89440 & 0.37701 \\
\hline
\end{tabular}




\section{Discussion}

This paper identifies the sources contributing to the formation of ERB in mountain tourism in China. The results show that tourists' ERB is influenced by different levels of tourism experience and place attachment.

Part of place attachment directly influences ERB. Place identity can promote general ERB, while nature bonding promotes general and particular ERB. It shows that the special natural environment of Qianshan Mountain makes the tourists enjoy and care about the mountain ecosystem. It shows that the tourists encourage each other to protect the environment and criticize those who abuse it [53]. At the same time, tourists have a strong emotional connection with the mountain ecosystem, which explains how they develop a special ERB such as picking up litter [10].

Tourist experience indirectly affects ERB through place attachment. Entertainment experience has a positive effect on place identity and nature bonding; aesthetic and escape experiences have positive effects on place identity, nature bonding and place dependence; education experience has positive effects on place identity and place dependence. The results show that tourists are most impressed by the sense of physical and mental freedom while in the mountains. This is the main reason for the formation of place attachment. The entertainment experiences of tourists improve their positive emotions and strengthen their relationship to the land [97]. It leads to the formation of place identity and nature bonding. In addition, knowledge and learning opportunities can improve tourists' emotions and understanding of Qianshan Mountain that will develop their place identity and place dependence [98].

The relationship between entertainment experience and place dependence in mountain tourism was not identified. Place dependence is the relationship between people and place at the levels of cognition (thought, knowledge, belief), practice (action and behavior), and emotion (mood and feeling) [23,99,100]. All three levels focus on the functional attributes of a place. However, tourist demand for entertainment experiences are focused on the physiological level [94]. Entertainment facilities and services are scarce in Qianshan Mountain, so it is difficult for tourists to develop place dependence with entertainment experiences.

The relationship between education experience and nature bonding of mountain tourism was not supported. Nature bonding focuses on the natural environment of the destination and the emotional connection between the tourist and environment [50]. In contrast, education experience emphasizes the cultural aspects of the destination [55]. Qianshan Mountain is home to many natural and ecological landscapes that enable tourists to experience feelings inspired by the beautiful aesthetics, while the landscapes with cultural aspects and knowledge elements are likely to attract tourists' attention. Therefore, tourists do not have an education experience in Qianshan Mountain. It is, however, difficult to promote the emotional connection between tourists and the mountain ecosystem.

The relationship between place identity and particular ERBs was not supported because tourists had little awareness of the ecological vulnerability of the mountain. They were largely unaware of environmental protection, so the tourists' behavior was at the level of general ERB and it is hard to generate particular ERB.

Neither hypothesis between place dependence and ERBs were supported. A possible reason is that place dependence, as a functional attachment to a particular place, has strong physical characteristics and demand properties [88,95]. However, the functional properties of place dependence are concentrated on aesthetic, escape, and education in Qianshan Mountain. The scenic spot fails to play these roles, and so it is not possible to establish a direct and close demand relationship between the tourists and ERB, which leads to place dependence failing to generate ERB.

\section{Conclusions}

This paper finds that tourist behaviors have a close relationship with their feelings and psychological changes. It demonstrates the relationship between the ERBs of tourists, their 
tourism experience and place attachment; and takes Qianshan Mountain as an example. The conclusions are as follows.

The internal psychological and emotional mechanism of ERB based on tourist experience is explored. Four types of tourist experience are shown to have different effects on ERBs through place identity, nature bonding and place dependence. The results show that escape and aesthetic experiences affect general and particular ERB through nature bonding. The relaxed atmosphere and picturesque scenery helps tourists understand the relationship between people and nature; and they might take action to protect nature and conserve the mountain landscape by adopting ERBs such as picking up garbage. Entertainment experience affects general ERB through place identity and nature bonding. Tourists may discuss environmental problems when they believe that the mountain landscape is part of the "self" and the emotional affinity towards nature through an entertainment experience. Education experience affects general ERB through place identity. The tourists care about environmental problems and educate themselves with knowledge of environmental protection when they immerse themselves in the mountain landscape. Therefore, mountain landscape can be designed from the perspective of an entertainment experience, landscape aesthetic, leisure atmosphere and with educational functions, so that tourists can spontaneously pay attention to environmental issues and participate in the practical activities of environmental protection.

\section{Theoretical and Managerial Implications}

\subsection{Theoretical Implications}

This paper focuses on the mountain tourism ecosystem and the ways in which tourists can implement ERB to support the coordinated development of tourism and ecology. It departs from the traditional view that tourist satisfaction or tourism experience is a factor in tourists' ERB and expands it to include the tourists' positive feelings about the destination. It breaks down the dimensions of the traditional tourism experience, such as hedonism, participation, novelty; or hedonism, involvement, novelty, local culture; and takes entertainment, education, aesthetics and escape as the dimensions. ERB follows the path of "experience-psychology-behavior." Place attachment, with a special focus on the human-land relationship, is taken as the traditional relationship of tourist experience and ERB. Meanwhile, considering the natural characteristics of mountain tourism, this paper gives up the traditional two-dimensional view of place attachment and takes nature bonding into the framework of place attachment, and shows the relationship of nature bonding and different tourism experiences or ERBs. Finally, a mechanism for the formation of tourist ERB in a mountain tourism ecosystem is identified.

\subsection{Managerial Implications}

Nature bonding is the key to ERB in mountain tourism. Entertainment experience has little influence on nature bonding in Qianshan Mountain. Therefore, Qianshan Scenic Area needs to expand its recreational facilities. Qianshan Mountain could build a natural rainbow slide and a zip-line to attract younger or more adventure-seeking tourists. In addition, planning and design should be implemented for tourists to enjoy natural entertainment, such as rope net climbing, or combination slide and swings. Evening and temple fair activities should also be offered. Mountain biking, marathons and other sport events can improve tourists' entertainment experiences.

Because of the weakness of place identity and place dependence, particular ERBs are largely absent in Qianshan Mountain. Qianshan Scenic could be designed according to the topography, shape, and trend of the mountain from an aesthetic perspective. Plant arrangement and landscape accessories could be designed from the perspective of their colors. The arrangement of plants from different distances and perspectives will create beautiful stratification and sequences in the landscape. In terms of escape, improvements could be made in food, hotel, and transportation. The dining environment should offer a variety of cave restaurants, temple restaurants, tree house restaurants, sky restaurants, and revolving 
restaurants on top of the mountain. Serving innovative dishes can enable the tourists to enjoy escape through a culinary experience. In terms of educational experience, there should be partnerships with schools, research institutions, and tourism institutions. Tourists can learn about nature, ecology, and living creatures through observation, exploration in nature schools, or in classrooms.

\section{Limitations and Future Research Directions}

The formation of ERB based on tourist experience and place attachment is applicable only to Qianshan Mountain in this paper. The applicability of the conclusions to other mountain ecosystems or tourist destinations remains to be further studied. As an important concept in the "human-land" relationship, place attachment is influenced by environment, society, culture, faith, sociology, psychology, and management. Whether other factors influence ERB through place attachment remain to be further studied. In addition, if these findings are compared with those of other scenic spots, the results would have greater significance.

Author Contributions: Conceptualization, D.W., E.W. and Y.Z.; data curation, J.M.; funding acquisition, D.W. and E.W.; investigation, K.L.; methodology, J.M.; project administration, E.W.; supervision, D.W. and E.W.; validation, K.L. and Y.Z.; visualization, K.L.; writing-original draft preparation, D.W. and K.L.; writing-review \& editing, Y.Z. All authors have read and agreed to the published version of the manuscript.

Funding: This work was supported by the National Natural Science Foundation of China [under grant number 71303027]; the Youth Foundation for Humanities and Social Sciences of the Ministry of Education [under grant number 16YJC630114]; the Social Science Planning Fund Project of Liaoning Province [under grant number L13DJY067, L15AJL007]; the Youth Program of Education Department of Liaoning Province [under grant number WQ2019005 ]; the Fundamental Research Funds for the Central Universities [under grant number N2011003]; the General Postdoctoral Program in China [grant number 2019M651102].

Institutional Review Board Statement: Not applicable.

Informed Consent Statement: Informed consent was obtained from all subjects involved in the study.

Data Availability Statement: Data presented in this study are available on request from the corresponding author.

Acknowledgments: We thank the reviewers for their thoughtful comments that helped improve the quality of this work.

Conflicts of Interest: The authors declare no conflict of interest.

\section{References}

1. Towner, J. The grand tour: A key phase in the history of tourism. Ann. Tour. Res. 1985, 12, 297-333. [CrossRef]

2. Gill, A.; Williams, P. Managing growth in mountain tourism communities. Tour. Manag. 1994, 15, 212-220. [CrossRef]

3. UNEP. Tourism and Mountains: A Practical Guide to Managing the Environmental and Social Impacts of Mountain Tours; UNEP: Arlington, VA, USA, 2007. Available online: https:/ / wedocs.unep.org/20.500.11822/7687 (accessed on 10 July 2021).

4. Dai, B. China's Mountain Tourism Market Has a Huge Scale, and Environmental Protection Should Be Taken into Account in Its Development. 2018. Available online: https://www.sohu.com/a/240281170_561670 (accessed on 10 July 2021).

5. Arrowsmith, C.; Inbakaran, R. Estimating environmental resiliency for the Grampians National Park, Victoria, Australia: A quantitative approach. Tour. Manag. 2011, 23, 295-309. [CrossRef]

6. Marsh, J. Mountains of the world: A global priority. Environ. Rev. 2002, 10, 191-193. [CrossRef]

7. Zhang, Y.L.; Zhang, J.; Zhang, H.L.; Cheng, S.W.; Guo, Y.R.; Jin-Hai, M.A. The impact of the cognition of landscape experience on tourist environmental conservation behaviors. J. Mt. Sci. 2015, 17, 501-517. [CrossRef]

8. Zhang, Y.l.; Zhang, J.; Zhang, H.O.; Zhang, R.Y.; Wang, Y.; Wei, Z.C. Residents' environmental conservation behaviour in the mountain tourism destinations in China: Case studies of Jiuzhaigou and Mount Qingcheng. J. Mt. Sci. 2017, 14, $2555-2557$. [CrossRef]

9. Geneletti, D.; Dawa, D. Environmental impact assessment of mountain tourism in developing regions: A study in Ladakh, Indian Himalaya. Environ. Impact Assess. Rev. 2009, 29, 229-242. [CrossRef] 
10. Hu, H.; Zhang, J.; Wang, C.; Yu, P.; Chu, G. What influences tourists' intention to participate in the Zero Litter Initiative in mountainous tourism areas: A case study of Huangshan National Park, China. Sci. Total Environ. 2019, 657, 1127-1137. [CrossRef]

11. Hsu, S.J.; Roth, R.E. An assessment of environmental literacy and analysis of predictors of responsible environmental behavior held by secondary teachers in Hualien county of Taiwan. Environ. Educ. Res. 1998, 4, 229-249. [CrossRef]

12. Wu, D.; Shen, C.; Wang, E.; Hou, Y.; Yang, J. Impact of the perceived authenticity of heritage sites on subjective well-being: A study of the mediating role of place attachment and satisfaction. Sustainability 2019, 11, 6148. [CrossRef]

13. Sivek, D.J.; Hungerford, H. Predictors of responsible behavior in members of three Wisconsin conservation organizations. J. Environ. Educ. 1989, 21, 35-40. [CrossRef]

14. Chang, L.C. The effects of moral emotions and justifications on visitors' intention to pick flowers in a forest recreation area in Taiwan. J. Sustain. Tour. 2010, 18, 137-150. [CrossRef]

15. Ballantyne, R.; Packer, J. Using tourism free-choice learning experiences to promote environmentally sustainable behaviour: The role of post-visit 'action resources'. Environ. Educ. Res. 2011, 17, 201-215. [CrossRef]

16. Iwata, O. Attitudinal determinants of environmentally responsible behavior. Soc. Behav. Personal. Int. J. 2001, 29, 183-190. [CrossRef]

17. Kaiser, F.G.; Wilson, M. Goal-directed conservation behavior: The specific composition of a general performance. Personal. Individ. Differ. 2004, 36, 1531-1544. [CrossRef]

18. Logar, I. Sustainable tourism management in Crikvenica, Croatia: An assessment of policy instruments. Tour. Manag. 2010, 31, 125-135. [CrossRef]

19. Teh, L.; Cabanban, A.S. Planning for sustainable tourism in southern Pulau Banggi: An assessment of biophysical conditions and their implications for future tourism development. J. Environ. Manag. 2007, 85, 999-1008. [CrossRef]

20. Poitras, L.; Donald, G. Sustainable wine tourism: The host community perspective. J. Sustain. Tour. 2006, 14, 425-448. [CrossRef]

21. Dickinson, J.E.; Robbins, D. Representations of tourism transport problems in a rural destination. Tour. Manag. 2008, 29, 1110-1121. [CrossRef]

22. Smith, J.W.; Siderelis, C.; Moore, R.L. The effects of place attachment, hypothetical site modifications and use levels on recreation behavior. J. Leis. Res. 2010, 42, 621-640. [CrossRef]

23. Halpenny, E.A. Pro-environmental behaviours and park visitors: The effect of place attachment. J. Environ. Psychol. 2010, 30, 409-421. [CrossRef]

24. Luo, W.B.; Zhang, X.H.; Cheng, Z.; Meng, B.; Timothy, D.J.; University, H.N. Research on the influencing factors of tourists' environmental responsibility behavior in urban natural scenic spots. China Popul. Res. Environ. 2017, 27, 161-169. [CrossRef]

25. Su, L.; Hsu, M.K.; Boostrom, R.E. From recreation to responsibility: Increasing environmentally responsible behavior in tourism. J. Bus. Res. 2020, 109, 557-573. [CrossRef]

26. Kang, M.; Moscardo, G. Exploring cross-cultural differences in attitudes towards responsible tourist behaviour: A comparison of Korean, British and Australian tourists. Asia Pac. J. Tour. Res. 2006, 11, 303-320. [CrossRef]

27. Hungerford, H.R.; Volk, T.L. Changing learner behavior through environmental education. J. Environ. Educ. 1990, $21,8-21$. [CrossRef]

28. Ballantyne, R.; Packer, J.; Falk, J. Visitors' learning for environmental sustainability: Testing short- and long-term impacts of wildlife tourism experiences using structural equation modelling. Tour. Manag. 2011, 32, 1243-1252. [CrossRef]

29. Aytülkasapoğlu, M.; Ecevit, M.C. Attitudes and behavior toward the environment: The case of Lake Burdur in Turkey. Environ. Behav. 2002, 34, 363-377. [CrossRef]

30. Juvan, E.; Dolnicar, S. Drivers of pro-environmental tourist behaviours are not universal. J. Clean. Prod. 2017, 166, 879-890. [CrossRef]

31. Lee, T.H.; Jan, F.H.; Yang, C.C. Conceptualizing and measuring environmentally responsible behaviors from the perspective of community-based tourists. Tour. Manag. 2013, 36, 454-468. [CrossRef]

32. Lee, T.H.; Jan, F.H. The effects of recreation experience, environmental attitude, and biospheric value on the environmentally responsible behavior of nature-based tourists. Environ. Manag. 2015, 56, 193-208. [CrossRef]

33. Cheng, T.M.; Wu, H.C. How do environmental knowledge, environmental sensitivity, and place attachment affect environmentally responsible behavior? An integrated approach for sustainable island tourism. J. Sustain. Tour. 2015, 23, 557-576. [CrossRef]

34. Zhou, X.; Tang, C.; Xing, B. Visitor engagement, relationship quality, and environmentally responsible behavior. Int. J. Environ. Res. Public Health 2020, 17, 1151. [CrossRef]

35. Confente, I.; Scarpi, D. Achieving environmentally responsible behavior for tourists and residents: A norm activation theory perspective. J. Travel Res. 2021, 60, 1196-1212. [CrossRef]

36. Beeho, A.J.; Prentice, R.C. Conceptualizing the experiences of heritage tourists: A case study of New Lanark World Heritage Village. Tour. Manag. 1997, 18, 75-87. [CrossRef]

37. Io, M.; Wan, P.Y.K. Relationships between tourism experiences and place attachment in the context of casino resorts. J. Qual. Assur. Hosp. Tour. 2018, 19, 45-65. [CrossRef]

38. Pine, B.J.; Gilmore, J.H. Welcome to the experience economy. Harv. Bus. Rev. 1998, 76, 97-105. [CrossRef] [PubMed]

39. Wong, I.A.; Fong, V.H.I. Examining casino service quality in the Asian Las Vegas: An alternative approach. J. Hosp. Mark. Manag. 2010, 19, 842-865. [CrossRef] 
40. $\mathrm{Xu}, \mathrm{Z}$.; Zhang, J. Antecedents and consequences of place attachment: A comparison of Chinese and Western urban tourists in Hangzhou, China. J. Destin. Mark. Manag. 2016, 5, 86-96. [CrossRef]

41. Schultz, P.W. Empathizing with nature: The effects of perspective taking on concern for environmental issues. J. Soc. Issues 2000, 56, 391-406. [CrossRef]

42. Devine-Wright, P.; Howes, Y. Disruption to place attachment and the protection of restorative environments: A wind energy case study. J. Environ. Psychol. 2010, 30, 271-280. [CrossRef]

43. Vaske, J.J.; Kobrin, K.C. Place attachment and environmentally responsible behavior. J. Environ. Educ. 2001, 32, 16-21. [CrossRef]

44. Raymond, C.M.; Brown, G.; Weber, D. The measurement of place attachment: Personal, community, and environmental connections. J. Environ. Psychol. 2010, 30, 422-434. [CrossRef]

45. Dutcher, D.D.; Finley, J.C.; Luloff, A.E.; Johnson, J.B. Connectivity with nature as a measure of environmental values. Environ. Behav. 2007, 39, 474-493. [CrossRef]

46. Ballantyne, R.; Packer, J.; Sutherland, L.A. Visitors' memories of wildlife tourism: Implications for the design of powerful interpretive experiences. Tour. Manag. 2011, 32, 770-779. [CrossRef]

47. Xu, S.; Kim, H.J.; Liang, M.; Ryu, K. Interrelationships between tourist involvement, tourist experience, and environmentally responsible behavior: A case study of Nansha Wetland Park, China. J. Travel Tour. Mark. 2018, 37, 1-13. [CrossRef]

48. Williams, D.R.; Vaske, J.J. The measurement of place attachment: Validity and generalizability of a psychometric approach. For. Sci. 2003, 49, 830-840. [CrossRef]

49. Williams, D.R.; Patterson, M.E.; Roggenbuck, J.W.; Watson, A.E. Beyond the commodity metaphor: Examining emotional and symbolic attachment to place. Leis. Sci. 1992, 14, 29-46. [CrossRef]

50. Powell, R.B.; Ham, S.H. Can ecotourism interpretation really lead to pro-conservation knowledge, attitudes and behaviour? Evidence from the Galapagos Islands. J. Sustain. Tour. 2008, 16, 467-489. [CrossRef]

51. Kals, E.; Schumacher, D.; Montada, L. Emotional affinity toward nature as a motivational basis to protect nature. Environ. Behav. 1999, 31, 178-202. [CrossRef]

52. Sims, R. Food, place and authenticity: Local food and the sustainable tourism experience. J. Sustain. Tour. 2009, 17, 321-336. [CrossRef]

53. Oh, H.; Fiore, A.M.; Jeoung, M. Measuring experience economy concepts: Tourism applications. J. Travel Res. 2007, 46, 119-132. [CrossRef]

54. Brodie, R.J.; Hollebeek, L.D.; Juric', B.; Illic', A. Customer engagement: Conceptual domain, fundamental propositions, and implications for research. J. Serv. Res. 2011, 14, 252-271. [CrossRef]

55. Chhetri, P.; Arrowsmith, C.; Jackson, M. Determining hiking experiences in nature-based tourist destinations. Tour. Manag. 2004, 25, 31-43. [CrossRef]

56. Kim, J.H.; Ritchie, J.; McCormick, B. Development of a scale to measure memorable tourism experiences. Eur. J. Tour. Res. 2012, 3 , 12-25. [CrossRef]

57. Tsai, C.-T. Memorable tourist experiences and place attachment when consuming local food. Int. J. Tour. Res. 2016, 18, 536-548. [CrossRef]

58. Gu, X.P.; Lewis, B.J.; Niu, L.J.; Da-Pao, Y.U.; Zhou, L.; Zhou, W.M.; Gong, Z.C.; Tai, Z.J.; Dai, L.M. Segmentation by domestic visitor motivation: Chang Bai Mountain Biosphere Reserve, China. J. Mt. Sci. 2018, 15, 1711-1727. [CrossRef]

59. Baker, D.A.; Crompton, J.L. Quality, satisfaction and behavioral intentions. Ann. Tour. Res. 2000, 27, 785-804. [CrossRef]

60. Kaltenborn, B.P. Nature of place attachment: A study among recreation homeowners in Southern Norway. Leis. Sci. 1997, 19, 175-189. [CrossRef]

61. Perkins, D.D.; Long, D.A. Neighborhood sense of community and social capital. In Psychological Sense of Community; Fisher, A.T., Sonn, C.C., Bishop, B.J., Eds.; Springer: Boston, MA, USA, 2002; pp. 291-318. [CrossRef]

62. Moore, R.L.; Graefe, A.R. Attachments to recreation settings: The case of rail-trail users. Leis. Sci. 1994, 16, 17-31. [CrossRef]

63. Kyle, G.; Graefe, A.; Manning, R.; Bacon, J. An examination of the relationship between Leisure activity involvement and place attachment among hikers along the Appalachian Trail. J. Leis. Res. 2003, 35, 249-273. [CrossRef]

64. Kim, J.H.; Ritchie, J.; Tung, V. The effect of memorable experience on behavioral intentions in tourism: A structural equation modeling approach. Tour. Anal. 2010, 15, 637-648. [CrossRef]

65. Clark, G.; Chabrel, M. Measuring integrated rural tourism. Tour. Geogr. 2007, 9, 371-386. [CrossRef]

66. Hay, R. Sense of place developmental context. J. Environ. Psychol. 1998, 18, 5-29. [CrossRef]

67. Twigger-Ross, C.L.; Uzzell, D.L. Place and identity processes. J. Environ. Psychol. 1996, 16, 205-220. [CrossRef]

68. Kai, V.H.; Jensen, Y. The meal experiences of à la carte restaurant customers. Scand. J. Hosp. Tour. 2005, 5, 135-151. [CrossRef]

69. Ryu, K.; Jang, S. Intention to experience local cuisine in a travel destination: The modified theory of reasoned action. J. Hosp. Tour. Res. 2006, 30, 507-516. [CrossRef]

70. Halpenny, E.A. Environmental Behaviour, Place Attachment and Park Visitation: A Case Study of Visitors to Point Pelee National Park. Ph.D. Thesis, University of Waterloo, Waterloo, ON, Canada, 2006. Available online: http://hdl.handle.net/10012/718 (accessed on 10 July 2021).

71. Korpela, K.M.; Hartig, T.; Kaiser, F.G.; Fuhrer, U. Restorative experience and self-regulation in favorite places. Environ. Behav. 2001, 33, 572-589. [CrossRef] 
72. Hosany, S.; Witham, M. Dimensions of cruisers' experiences, satisfaction, and intention to recommend. J. Travel Res. 2009, 49, 351-364. [CrossRef]

73. Kastenholz, E.; Marques, C.P.; Carneiro, M.J. Place attachment through sensory-rich, emotion-generating place experiences in rural tourism. J. Destin. Mark. Manag. 2020, 17, 100455. [CrossRef]

74. Pine, B.J.; Gilmore, J.H. The Experience Economy: Work Is Theatre and Every Business a Stage; Harvard Business School Press: Boston, MA, USA, 1999. [CrossRef]

75. Boorstin, D.J. The Image: A Guide to Pseudo-Events in America; Vintage Books, Inc.: New York, NY, USA, 1987.

76. MacCannell, D. Staged authenticity: Arrangements of social space in tourist settings. Am. J. Sociol. 1973, 79, 589-603. [CrossRef]

77. Kyle, G.; Graefe, A.; Manning, R.; Bacon, J. Effects of place attachment on users' perceptions of social and environmental conditions in a natural setting. J. Environ. Psychol. 2004, 24, 213-225. [CrossRef]

78. Han, X.; Tian, T.; Sun, B. A “perception-identity-engagement" model for the tourism virtual community. Tour. Trib. 2016, 31, 61-70. [CrossRef]

79. Weiler, B.; Ham, S. The Encyclopedia of Ecotourism; CABI Publishing: Wallingford, UK, 2000; Chapter 30. [CrossRef]

80. Smith-Sebasto, N.J.; D'Costa, A. Designing a Likert-type scale to predict environmentally responsible behavior in undergraduate students: A multistep process. J. Environ. Educ. 1995, 27, 14-20. [CrossRef]

81. Stern, P.C. Toward a coherent theory of environmentally significant behavior. J. Soc. Issues 2000, 56, 407-424. [CrossRef]

82. Walker, G.J.; Chapman, R. Thinking like a park: The effects of sense of place, perspective-taking, and empathy on proenvironmental intentions. J. Park Recreat. Adm. 2003, 21, 71-86. Available online: https://js.sagamorepub.com/jpra/article/ view / 1492 (accessed on 10 July 2021).

83. Ramkissoon, H.; Graham Smith, L.D.; Weiler, B. Testing the dimensionality of place attachment and its relationships with place satisfaction and pro-environmental behaviours: A structural equation modelling approach. Tour. Manag. 2013, 36, 552-566. [CrossRef]

84. Tonge, J.; Ryan, M.M.; Moore, S.A.; Beckley, L.E. The effect of place attachment on pro-environment behavioral intentions of visitors to coastal natural area tourist destinations. J. Travel Res. 2015, 54, 730-743. [CrossRef]

85. Lee, T.H.; Jan, F.H. The influence of recreation experience and environmental attitude on the environmentally responsible behavior of community-based tourists in Taiwan. J. Sustain. Tour. 2015, 23, 1-32. [CrossRef]

86. Cheng, T.M.; Wu, C.H.; Huang, L.M. The influence of place attachment on the relationship between destination attractiveness and environmentally responsible behavior for island tourism in Penghu, Taiwan. J. Sustain. Tour. 2013, 21, 1166-1187. [CrossRef]

87. Brown, G.; Smith, A.; Assaker, G. Revisiting the host city: An empirical examination of sport involvement, place attachment, event satisfaction and spectator intentions at the London Olympics. Tour. Manag. 2016, 55, 160-172. [CrossRef]

88. Zhang, Y.; Zhang, H.L.; Zhang, J.; Cheng, S. Predicting residents' pro-environmental behaviors at tourist sites: The role of awareness of disaster's consequences, values, and place attachment. J. Environ. Psychol. 2014, 40, 131-146. [CrossRef]

89. Kyle, G.T.; Mowen, A.J.; Tarrant, M. Linking place preferences with place meaning: An examination of the relationship between place motivation and place attachment. J. Environ. Psychol. 2004, 24, 439-454. [CrossRef]

90. Barr, S.; Shaw, G.; Coles, T. Sustainable lifestyles: Sites, practices, and policy. Environ. Plan. A 2011, 43, 3011-3029. [CrossRef]

91. Lee, T.H. Influence analysis of community resident support for sustainable tourism development. Tour. Manag. 2013, 34, 37-46. [CrossRef]

92. Stedman, R.C. Toward a social psychology of place: Predicting behavior from place-based cognitions, attitude, and identity. Environ. Behav. 2002, 34, 561-581. [CrossRef]

93. Hair, J.F.; Sarstedt, M.; Ringle, C.M.; Mena, J.A. An assessment of the use of partial least squares structural equation modeling in marketing research. J. Acad. Mark. Sci. 2012, 40, 414-433. [CrossRef]

94. Sarstedt, M.; Ringle, C.M.; Hwa, C.J.; Ting, H.; Moisescu, O.I. Structural model robustness checks in PLS-SEM. Tour. Econ. 2020, 26, 531-554. [CrossRef]

95. Hwang, H.; Malhotra, N.K.; Kim, Y.; Tomiuk, M.A.; Hong, S. A comparative study on parameter recovery of three approaches to structural equation modeling. J. Mark. Res. 2010, 47, 699-712. [CrossRef]

96. Hair, J.F.; Ringle, C.M.; Sarstedt, M. PLS-SEM: Indeed a silver bullet. J. Mark. Theory Pract. 2011, 19, 139-152. [CrossRef]

97. Chiu, Y.; Lee, W.I.; Chen, T.H. Environmentally responsible behavior in ecotourism: Antecedents and implications. Tour. Manag. 2014, 40, 321-329. [CrossRef]

98. Ramkissoon, H.; Mavondo, F.T. The satisfaction-place attachment relationship: Potential mediators and moderators. J. Bus. Res. 2015, 68, 2593-2602. [CrossRef]

99. Ramkissoon, H.; Mavondo, F.T. Proenvironmental behavior: Critical link between satisfaction and place attachment in Australia and Canada. Tour. Anal. 2017, 22, 59-73. [CrossRef]

100. Ryan, R.L.; Kaplan, R.; Grese, R.E. Predicting volunteer commitment in environmental stewardship programmes. J. Environ. Plan. Manag. 2001, 44, 629-648. [CrossRef] 